\title{
Dendrometer Stem Monitoring of Tomato Plants Attacked by Whiteflies in Greenhouses
}

\author{
Federico Hahn* \\ Irrigation Department, Universidad Autonoma Chapingo, Texcoco, Mexico
}

ISSN: 2637-7659

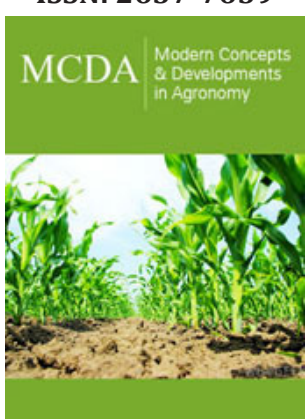

*Corresponding author: Federico Hahn, Irrigation Department, Universidad Autonoma Chapingo, Texcoco, Mexico

Submission: 侮 May 27, 2021

Published: 階June 18, 2021

Volume 8 - Issue 5

How to cite this article: Federico Hahn. Dendrometer Stem Monitoring of Tomato Plants Attacked by Whiteflies in Greenhouses. Mod Concep Dev Agrono. 8(5). MCDA. 000700. 2021. DOI: 10.31031/MCDA.2021.08.000700

Copyright@ Federico Hahn. This article is distributed under the terms of the Creative Commons Attribution 4.0 International License, which permits unrestricted use and redistribution provided that the original author and source are credited.

\begin{abstract}
Mexico is one of the largest producers of tomato and the first exporter in North America and greenhouse tomatoes have to be grown without pesticides. Tomato plants are severely attacked by whiteflies that suck their leaves for sap and transmit viruses. An experiment was carried out in a greenhouse at the University campus and an insect net protected half of the transplanted tomatoes from insects. Whiteflies (Trialeurodes vaporariorum) were identified in the other tomato plants grown in tezontle substrate pots. Whitefly population was obtained by counting flies in upper leaves and with the use of a custom made vibrator. Plastic covered plates only indicated whitefly presence, but 10-minute vibration and leaf counting were similar. As the vibration increased to 15 minutes the number of flies sticked into the plastic doubled. Point dendrometers were fixed to the stem of two healthy and two infested plants to determine daily growth during the entire season. Plants infested with a population count of 50 whiteflies in the superior eight leaves showed limited growth and a lower shrinkage of $0.5 \mathrm{~mm}$ was encountered after midday. As fly density increased to 20 whiteflies per leaf, transpiration decreased and plant stress increased, ending in a thinner stem.
\end{abstract}

Keywords: Whitefly population methods; Dendrometer; Trialeurodes vaporariorum; Stem hrinkage; Plant vibrator

\section{Introduction}

Tomato (Lycopersicon esculentum) is grown extensively in greenhouses around the world as it is highly demanded by the fresh market and processing industries. Mexico is the tenth largest producer of tomatoes in the world growing 4.04 million tons annually [1]. Total planted area for tomatoes had been declining in Mexico for several years, being of 53,300 hectares during the market season 2017/18. Tomato produced in Sinaloa and Baja California continue to move from open field production to greenhouses; This action obtains greater yields in a smaller cultivated area.

Trialeurodes vaporariorum is highly attracted to some commercially available tomato cultivars [2] and $80 \%$ of tomato loss has been reported [3,4]. The most important whitefly encountered in South America is Trialeurodes vaporariorum Westwood being reported at Colombia [2], Costa Rica [5] and Brazil [6]. Adults feed by sucking juices from the underside of the leaf and produce a honey dew which causes leaf darkening. The development cycle from egg to adult takes up to one month [7]. Flies are responsible for severe physiological disorders in tomato, as irregular ripening reported in Culiacan, Mexico [4].

Management of flies should be carried out without insecticides. Biotechnical control involves techniques that act on insects' behavior via visual or olfactory stimuli. It guides them to an attractive visual or olfactory source before being trapped [3]. Fruit orchards use McPhail-type liquid traps and yellow bottles to attract flies and drown them afterwards [8]. Fruit flies have natural enemies, which generally attack the eggs or larvae, especially when the larvae emerge from the fruit to pupate in the soil.

Dendrometers monitor physiological activity, so it has become a reliable plant water status indicator. Plant water status can only be obtained from plant measurements as it controls many physiological processes [9]. Diurnal stem contraction results from the water taken up 
by the plant and lost from transpiration. At night the elastic stem tissues grows storing carbohydrates and water. Stem diameter variation has become popular for irrigation scheduling, mainly under deficit irrigation conditions. It has been widely reported in fruit trees including olives [10], citric trees [11], nectarines [12] and peaches [13]. Dendrometers were used in greenhouse tomato plants its values was correlated successfully with soil water content [9]. Maximum daily shrinkage (MDS) and air vapor pressure deficit (VPD) ratio remained constant when tomato plants were not water stressed [14].

In this research whitefly dynamics within the greenhouse at different phenological stages was quantified using a vibrator and also by counting fly quantity in top leaves. Another main goal of this research is to measure stem variations by homemade resistance dendrometers. If whiteflies affect tomato plants by sap feeding, plant weakening will occur. Plant status monitored with a dendrometer will be able to determine plant stress. If a monitoring difference is encountered it will help in starting an integrated pest management routine in-time.

\section{Material and Methods}

\section{Experimental setup}

Tomato (Solanum lycopersicum) growing greenhouses are located in Chapingo, Estado Mexico (19² 29’ N, 98 54' W, 2250m ASL) and have automated fertigation system. Commercial hybrid 'El Cid F1' Saladette tomato seedlings were transplanted on March 22,
2019, in 10L tezontle bags as described by Salazar et al. [15]. Eight drip irrigation events per day were carried out using $8 \mathrm{~L} \cdot \mathrm{h}-1$ emitters, having a different timing per event according to its phenological stage. Steiner nutrient solution was used for fertilization, presenting an electrical conductivity and $\mathrm{pH}$ of $2.3 \mathrm{dS} \mathrm{m}-1$ and 6.4, respectively. In the experiment, 20 tomato plants were cultivated at a plant density of 2.4 plants $\mathrm{m}-2$ inside a small greenhouse of $5 \mathrm{~m}$ x $5 \mathrm{~m}$ x $4 \mathrm{~m}$ (width $\mathrm{x}$ length $\mathrm{x}$ height). Tomato plants were grown inside two sections separated by a thin insect net. Ten plants grew healthy meanwhile the other ten were whitefly-infested.

\section{Whitefly population}

Greenhouse whiteflies from the experimental station of the Universidad Autonoma Chapingo located in Mexico, were identified as Trialeurodes vaporariorum Westwood [16]. Two methods were used for monitoring flies: sticky traps and whitefly adult leaf counting. Whitefly monitoring used 25-cm diameter yellow sticky traps (Figure 1a) placed $15 \mathrm{~cm}$ below top plant canopy. Adult flies were counted on different phenological stages from vegetative development, through flowering until the second harvest [17]. Whiteflies ended glued to the plastic sticky material (Figure 1b) of the plates. Traps were removed once a week and the number of adults counted. A more efficient method to detect flies with a sticky-plastic wall uses a gear motor (Bodine, USA) fixed to the $5 \mathrm{~cm}$ square greenhouse structure. An eccentric plate (Figure 1c) was moved by the motor and a wire (Figure 1d) fixed to the bottom of the plate make plants vibrate.
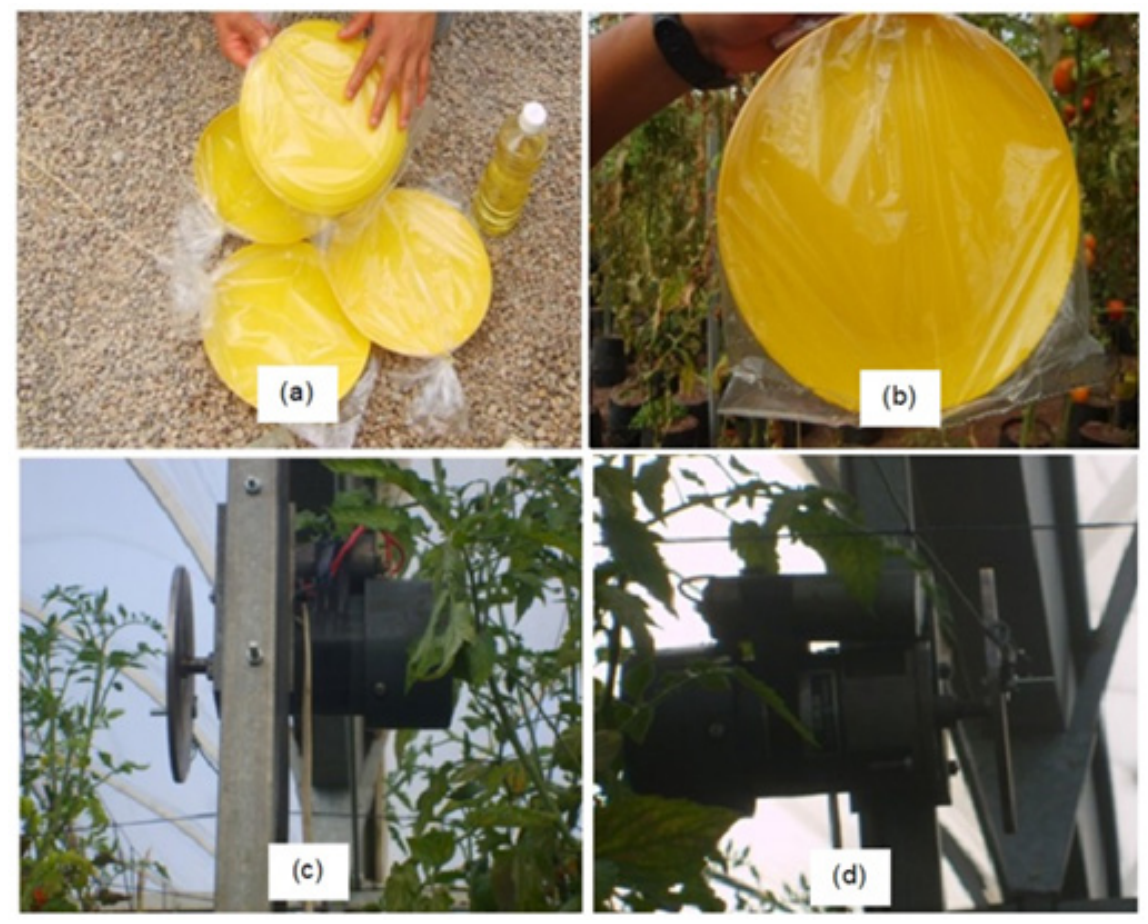

Figure 1: (a) Preparation of yellow plates with plastic cover,

(b) being placed within the greenhouse.

(c) Vibrator unit showing motor and plate and

(d) its connection to the plant wires. 
The more exact technique for quantifying whitefly adults, counted adult flies lying on the first and second fully expanded leaves from the top [2]. Photographs were taken with a Huawei Y5 2019 smartphone having a 3-megapixel camera with an f/1.8 aperture. As adult whitefly move less, counts were performed early in the morning.

Data was collected four times during different phenological stages. The first sampling occurred on April $24^{\text {th }}$, one month after transplanting, being plants under vegetative growth. On June $24^{\text {th }}$ flowering plants were monitored. The last two samplings took place on July $24^{\text {th }}$ and August $24^{\text {th }}$ during the first and second harvest respectively.

\section{Dendrometer setup and monitoring}

Stem diameter variations were measured on one plant using a linear commercial variable displacement transducer (LVDT) (mod 2.5 DF, Solartron Metrology, UK) and compared against a linear resistor dendrometer built at the Universidad Autonoma Chapingo and placed $2 \mathrm{~cm}$ higher. The linear resistance sensor (model 9605R1.7KL2.0, BEISensors, USA) was attached to the stem using a stainless steel holder. The sensor signal was logged (Logbox AA,
Novus Automation, Canoas, Brasil) at 30-s intervals and averaged every $5 \mathrm{~min}$. Two linear resistance dendrometers were placed in healthy plants and another two in whitefly infested plants. Initial values of the diameter were measured with an electronic caliper when the experiment started [18]. Measurements were acquired daily after flowering until the second tomato harvest. Six-week old tomato infested plants were flowering and their stem data was retrieved and compared with healthy stem values. Dendrometer measurements from healthy and whitefly infested tomato plants were analyzed in a daily pattern and within 3-day time intervals searching for additional results.

\section{Result}

All the plants without the screen presented adult flies. The number of flies per plant are shown in Figure 2, being of 2-3 adults per leaf during the flowering stage. After one month fruits matured and the central plants $(4,5$ and 6$)$ overpassed the tolerance threshold of 10 adults per leaf [19]. The lateral plants were less susceptible to fly attack due to sunlight, air and higher relative humidity. During the second harvest in August whitefly population doubled. The leaves at the top of the plant wilted, being stressed and losing its green color to become yellow.

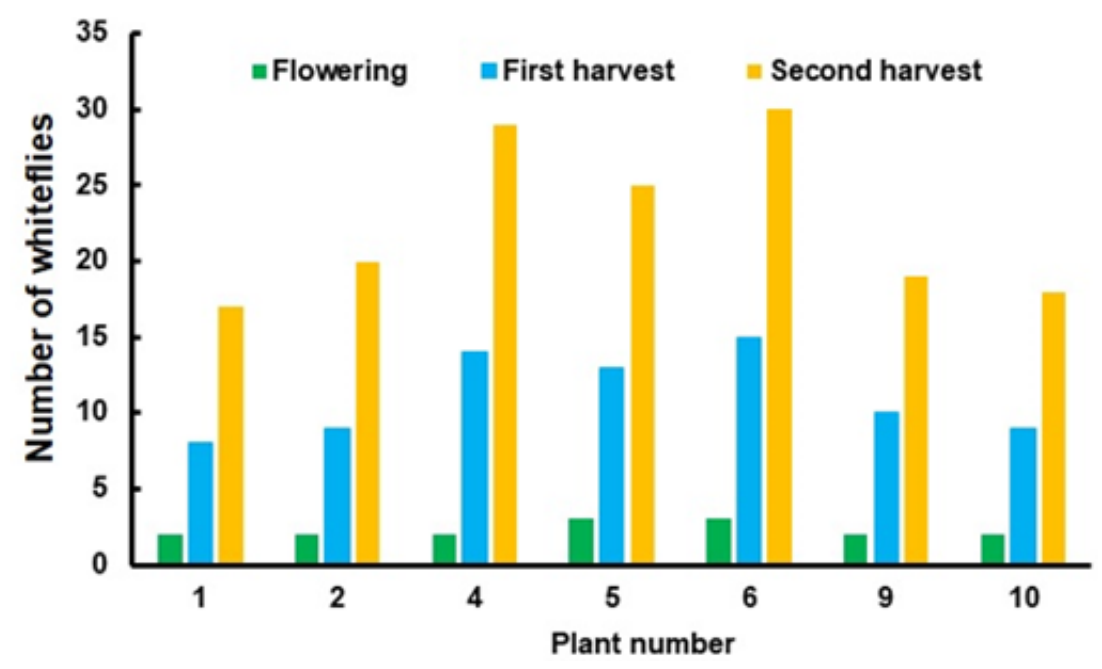

Figure 2: Whitefly counted in six plants during flowering and harvest.

The monitoring systems for whitefly population analysis are shown in Table 1. Flies were not present during vegetative growth. During flowering and fruiting stages, fly population increased and whiteflies attached to the sticky-plastic by the $10 \mathrm{~min}$-vibrator were similar to the results obtained by leaf counting. In both sampling techniques whitefly population increased with plants age. As the vibrator worked for 5 minutes more, the quantity of whiteflies doubled (Table 1). Motor speed remained constant being of 65RPM.

The results of Table 1 show that the yellow plates are not accurate for population counting. The plates presented similar results during flowering and fruiting phenological stages (Figure 3). The adults glued to the plastic show a very high population that probably came from another leaves within the bottom of the plant (Figure 4d). Circles show adults in the plastic after 10 minutes of operation (Figure 4c).
Table 1: Comparison of counting whiteflies using three techniques during vegetative development, flowering and harvest.

\begin{tabular}{|c|c|c|c|c|}
\hline & \multicolumn{3}{|c|}{ Whitefly Population } \\
\hline & $\begin{array}{c}\text { April 24, Veg } \\
\text { Development }\end{array}$ & $\begin{array}{c}\text { June 24, } \\
\text { Flowering }\end{array}$ & $\begin{array}{c}\text { July 24, 1st } \\
\text { Harvest }\end{array}$ & $\begin{array}{c}\text { August } \\
\text { 24, 2nd } \\
\text { Harvest }\end{array}$ \\
\hline $\begin{array}{c}\text { Plates } \\
\text { hanging }\end{array}$ & 0 & $2.1 \pm 0.8$ & $5.1 \pm 0.8$ & $8.9 \pm 0.8$ \\
\hline $\begin{array}{c}\text { Leaf } \\
\text { counting }\end{array}$ & 0 & $2.5 \pm 0.5$ & $12 \pm 2.78$ & $23.6 \pm 4.7$ \\
\hline $\begin{array}{c}\text { Vibrator 10 } \\
\text { min }\end{array}$ & 0 & $3.3 \pm 0.9$ & $14.3 \pm 1.2$ & $25.1 \pm 0.8$ \\
\hline $\begin{array}{c}\text { Vibrator 15 } \\
\text { min }\end{array}$ & 0 & $8.6 \pm 2.2$ & $26.6 \pm 3.1$ & $48.3 \pm 3.9$ \\
\hline
\end{tabular}



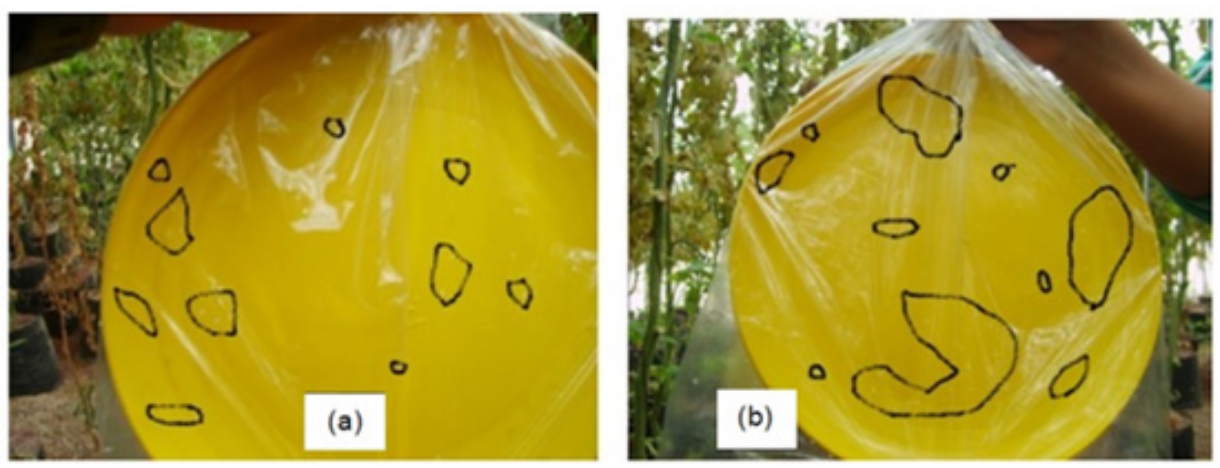

Figure 3: (a) Whiteflies trapped in plates hanging in the greenhouse for one week during flowering and (b) during fruiting.
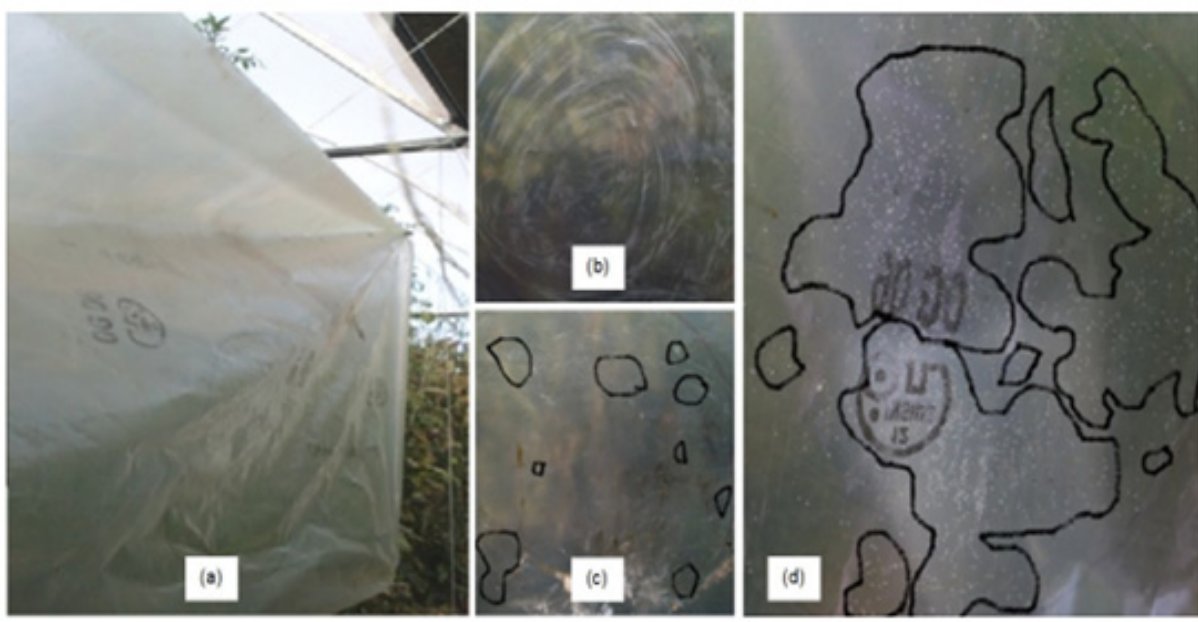

Figure 4: Plastic hanged by

(a) the side of the plants,

(b) once vibration takes place,

(c) after 10 minutes and

(d) after 15 minutes showing sticked whiteflies.

\section{Dendrometer monitoring}

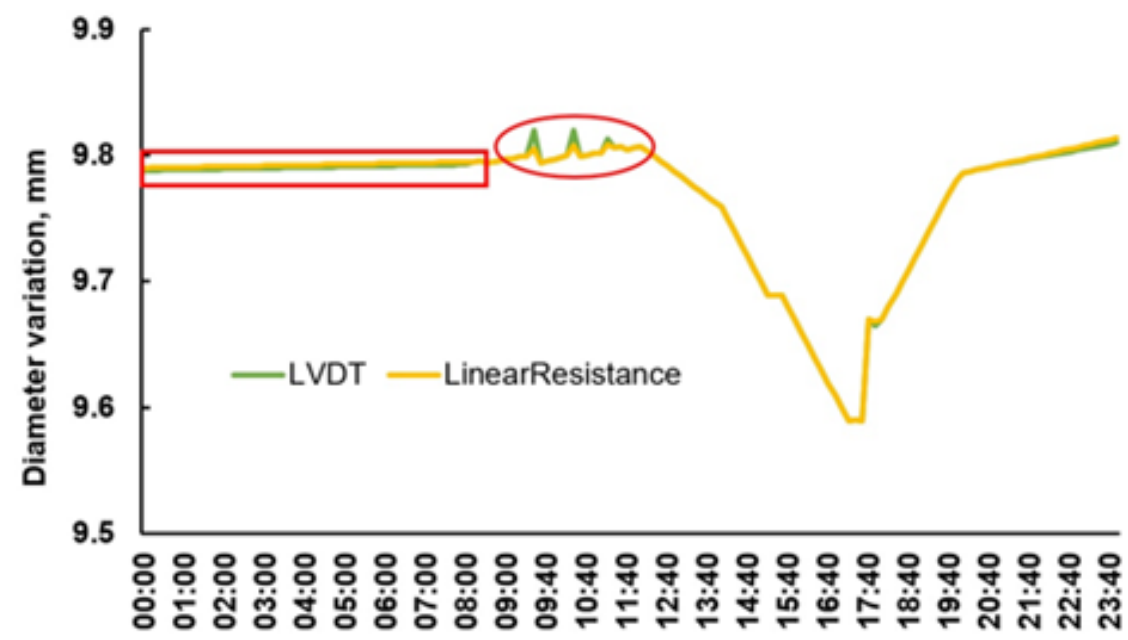

Figure 5: Stem diameter variation on the same plant taken by LVDT and resistance sensors. 
The LVDT commercial dendrometer was compared against the linear resistance sensor connected to the data logger. The linear resistance was fed by a linear current source to reduce measurement errors when the battery voltage discharges. A low pass filter within the microcontroller eliminated high frequency noise coming from the circuit oscillators. Very small measurement errors after midnight were noted with the resistance dendrometer (Figure 5). These errors resulted from high air relative humidity (RH) that was over $90 \%$ before sunrise. The point dendrometer based in the LVDT responds quicker to rapid changes as shown by the green peaks of Figure 5 at 10:00 and 11:00am.

At the end of July during the first harvest (160 days after transplanting) stem diameter differences were noted between a healthy and an infested plant. The healthy plant during the night before sunrise and after sunset has a continuous growth and achieves maximum shrinkage at 13:40 (Figure 6). Every time an irrigation event takes place stem grows and a peak observed. The plant attacked by 50 flies shrinked less $0.5 \mathrm{~mm}$ from a lower transpiration rate and during the night no growth was recorded. After analyzing the dendrometer measurements for three days 180 days after transplanting, the healthy plant shows continuous growth, meanwhile the highly infested plant shows a decrease in diameter size as it loses vigor (Figure 7). The healthy plant grows $1.88 \mu \mathrm{m}$ per day, meanwhile the severe infested plant decreases its diameter girth by $0.392 \mu \mathrm{m}$ per day. The infested plant with less than 50 flies over the top leaves presents a diameter growth of $0.29 \mu \mathrm{m}$ per day (Figure 7).

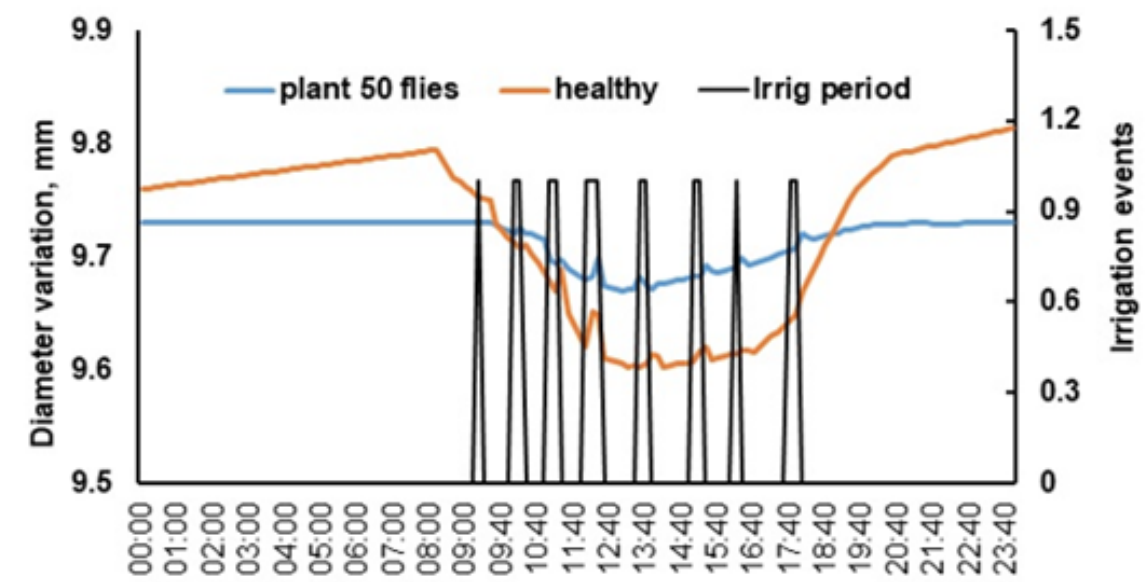

Figure 6: Stem diameter variation during an entire day from two tomato plants (healthy and fly infested) being irrigated during 8 events.

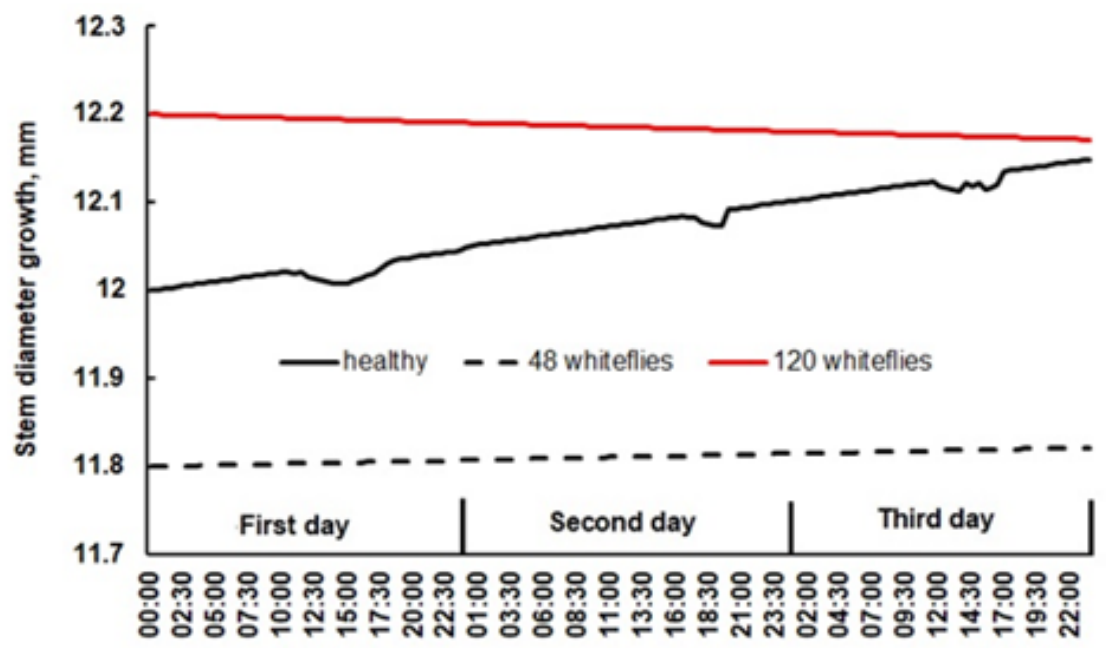

Figure 7: Stem diameter growth during three continuous days at the end of the first harvest of a healthy plant, a lightly and a heavily infested plant.

\section{Discussion}

Traps are used to study fruit fly communities, but captured flies have not been correlated with the real number of fruit flies [20]. The yellow color visual traps that were used track fly populations, but are unpractical. Their limited selectivity causes pollinators to end glued to the plastic. Population did not decrease by setting traps in a single plot of the trials [2] and proliferated more with tomato fruiting. Between the first and second harvest whitefly population 
increased greatly. It is important to instruct personnel in sanitary and pest management to reduce whitefly propagation. Female adults found within the greenhouse and in the plastic traps were more than males. Brevault [7] also observed a majority of female adults in the tomato crop laying eggs.

Environmental factors affect whitefly lifespan. As temperature increases, whiteflies adult longevity and fecundity decreases [21]. A negative relationship ( $\mathrm{r}=-0.045)$ between whitefly population and average relative humidity suggests that whitefly population is not dependent on humidity [22]. Rainfall may lead to significant mortality in adult whiteflies, so whitefly populations remain within the greenhouse during the summer.

Tomato greenhouse production are using soilless media such as rockwool, peat, perlite or tezontle as they are pathogen-free and can be disinfected for reutilization. Root zone sensors are being used for irrigation scheduling but during soil moisture monitoring many drawbacks appear. Between sensors sensitivity, accuracy, repeatability, salinity variability and temperature dependence are noted [23]. In order to be used in tomato greenhouses, sensors should work with different substrates and several problems have to be solved. A dendrometer installed in the stem could provide a signal nondependent with soil salinity or substrate variable nutrient alkalinity.

The dendrometer connected to a data logger must always be in contact with the plant surface and avoid direct solar radiation [24]. LVDT sensors are used by most researchers where thin stems are sampled [25], but tomato plant stem was measured with precision with laser displacement sensors [26]. In our comparison between linear resistance and LVDT sensors the final error after 4 months of measurement was of only $0.01 \mathrm{~mm}$.

Changes in fruit load and tomato stem age bring important changes in stem variation evaluation. Tomato plants have a constant fruit load throughout the growing season as fruits are picked continuously [25]. They reported that previous to harvest, fruit sink strength dominated water transport towards the fruits. Plants with higher illumination in the edges of the greenhouse grew faster than plants in the center of the greenhouse. Plants at the edge of the greenhouse show larger stem shrinkage during the day and after sunset, plants stem grow again [18]. Daily stem growth behavior follows an inverse pattern as water and sap flow through the plant.

We saw that healthy tomato plants having high sap flow rates presented large maximum daily stem shrinkage (Figure 6) values, while infested plants with low circulating sap flow and transpiration showed minimum shrinkage. In Figure 6, 50 flies per plant do not represent a severe and harmful infestation [19]. As flies per plant increased over 100 adults, plant stress was noted with a shrinkage of just $0.1 \mathrm{~mm}$; this graph was not plotted. Figure 7 shows signatures of stem growth during a three-day continuous period. Healthy tomato plants present leaf transpiration and stem shrinkage, experiencing a final daily stem growth. Water stressed plants generally show low rates of stem growth [27]. However, a severe infested plant is completely stressed, leaves fall and stem diameter decreases. Leaf wilting and stem diameter response have been related to plant water stress [26]. Water stress affects soil water potential and stomatal conductance $[28,29]$.

\section{Conclusion}

Whitefly population was counted with a vibrator that worked for ten minutes. Its values were close to the plant whitefly population counted in the top two leaf layers. As the plant grew the infestation increased and longer vibrator time could help to decrease flies inside the greenhouse.

A point home built resistance dendrometer monitored tomato stem changes during an entire season. It was found that whitefly Trialeurodes vaporariorum Westwood sucks sap from leaves, stressing the plant. It was noted a lower stem shrinkage with infested plants than with healthy ones. As time passes, plants' vigor is lost and stem growing reverses becoming thinner (Figure 7).

\section{Acknowledgement}

I will like to thank MI Jesus Antonio Garcia Martinez who built the dendrometer and the DGIP who funded the project 21013-DTT65.

\section{References}

1. FAOSTAT (2016) Food and agriculture data. Rome, Italy.

2. Lucatti AF, Alvarez AE, Machado CR, Gilardón E (2010) Resistance of tomato genotypes to the greenhouse whitefly Trialeurodes vaporariorum (West.). Neotropical Entomology 39(5): 792-798.

3. Ryckewaert P, Deguine J, Brévault T, Vayssières J (2010) Fruit flies (Diptera: Tephritidae) on vegetable crops in Reunion Island (Indian Ocean): State of knowledge, control methods and prospects for management. Fruits 65(2): 113-130.

4. Ascencio Ada, Avila M, González J, Olán M, Espinosa E, et al. (2018) Tomato irregular ripening in the Culiacan Valley, Mexico. Revista Fitotecnia Mexicana 41(3): 265-273.

5. Can Vargas X, Barboza N, Fuchs E, Hernández E (2020) Spatial distribution of whitefly species (Hemiptera: Aleyrodidae) and identification of secondary bacterial endosymbionts in tomato fields in Costa Rica. Journal of Economic Entomology 113(6): 2900-2910.

6. de Moraes LA, Muller C, Bueno RCO, Santos A, Bello V (2018) Distribution and phylogenetics of whiteflies and their endosymbiont relationships after the Mediterranean species invasion in Brazil. Sci Rep 8(1): 14589.

7. Brevault T, Quilici S (2009) Oviposition preference in the oligophagous tomato fruit fly, Neoceratitis cyanescens. Entomologia Experimentalis et Applicata 133(2): 165-173.

8. Robinson AS, Hooper G (1989) Fruit flies, their biology, natural enemies and control. Elsevier, Amsterdam, Netherlands.

9. Meng Z, Duan A, Chen D, Dassanayake KB, Wang X, et al. (2017) Suitable indicators using stem diameter variation-derived indices to monitor the water status of greenhouse tomato plants. PLoS ONE 12(2): e0171423.

10. Cuevas MV, Torres Ruiz JM, Alvarez R, Jiménez MD, Cuerva J, et al. (2010) Assessment of trunk diameter variation derived indices as water stress indicators in mature olive trees. Agricultural Water Management 97(9): 1293-1302.

11. Velez JE, Intrigliolo DS, Castel JR (2007) Scheduling deficit irrigation of citrus trees with maximum daily trunk shrinkage. Agricultural Water Management 90(3): 197-204. 
12. Naor A, Gal Y, Peres M (2006) The inherent variability of water stress indicators in apple, nectarine and pear orchards, and the validity of a leaf-selection procedure for water potential measurements. Irrigation Science 24: 129-135.

13. Conejero W, Mellisho CD, Ortuño MF, Moriana A, Moreno F, et al. (2011) 655 Using trunk diameter sensors for regulated deficit irrigation scheduling in early maturing peach trees. Environmental and Experimental Botany 71(3): 409-415.

14. Gallardo M, Thompson RB, Valdez LC, Fernandez D (2006) Use of stem diameter variations to detect plant water stress in tomato. Irrigation Science 24: 241-255.

15. Salazar R, Sánchez AC, López IL (2020) Indicators for assessing water energy and labor use performance in a low-tech greenhouse. Revista Chapingo Serie Horticultura 26(2): 95-110.

16. García M, Sánchez E, Robles P, Álvarez M (2007) Toxicity of Petiveria alliacea L. on greenhouse whitefly (Trialeurodes vaporariorum WEST). Interciencia 32(2): 121-125.

17. Gusmão MR, Picanço MC, Zanuncio JC, Silva DJH, Barrigossi JAF (2005) Standardised sampling plan for Bemisia tabaci (Homoptera: Aleyrodidae) in outdoor tomatoes. Scientia Horticulturae 103(4): 403412.

18. Swaef T, Verbist K, Cornelis W, Steppe K (2011) Tomato sap flow, stem and fruit growth in relation to water availability in rockwool growing medium. Plant and Soil 350: 237-252.

19. Polack A (2005) Manejo integrado de moscas blancas. [Integrated management of whiteflies]. Boletín Hortícola № 31. INTA-San Pedro, Argentina, p. 7.

20. Efrom CFS (2009) Studies of spatial distribution and population fluctuations of fruit flies. In: Bandeira RB (Ed.), Current trends in Fruit Fly Control on Perennial Crops and Research Prospects, pp: 117-133.
21. Manzano M, van Lenteren J (2009) Life history parameters of Trialeurodes vaporariorum (Westwood) (Hemiptera: Aleyrodidae) at different environmental conditions on two bean cultivars. Neotropical entomology 38(4): 452-458.

22. Khan MMH (2019) Effect of temperature and relative humidity on the population dynamics of brinjal and tomato infesting whitefly, Bemisia tabaci. Jahangirnagar University Journal of Biological Sciences 8(1): 8386.

23. Pardossi A, Incrocci L, Incrocci G, Malorgio F, Battista P, et al. (2009) Root zone sensors for irrigation management in intensive agriculture. Sensors 9(4): 2809-2835.

24. Fernández JE (2017) Plant-based methods for irrigation scheduling of woody crops. Horticulturae 3(2): 35.

25. Swaef T, Steppe K (2010) Linking stem diameter variations to sap flow, turgor and water potential in tomato. Functional Plant Biology 37(5): 429-438.

26. Wakamori K, Mineno $\mathrm{H}$ (2019) Optical flow-based analysis of the relationships between leaf wilting and stem diameter variations in tomato plants. Plant Phenomics 2019: 9136298.

27. Goldhamer DA, Fereres E (2001) Irrigation scheduling protocols using continuously recorded trunk diameter measurements. Irrig Sci 20: 115125 .

28. Darshanee HLC, Ren H, Ahmed N, Zhang Z, Liu YH, et al. (2017) Volatilemediated attraction of greenhouse whitefly Trialeurodes vaporariorum to tomato and eggplant. Frontiers Plant Science 8: 1285.

29. Perring T, Stansly P, Liu TX, Smith H, Andreason S (2018) Whiteflies: Biology, Ecology, and Management. In: Wakil W, Brust GE, Perring TM (Eds.), Sustainable Management of Arthropod Pests of Tomato. Academic Press, Elsevier, Netherlands, pp: 73-110. 